\title{
Evaluation of indigenous fungal entomopathogens and aqueous leaf extract of Annona muricata against Polyphagotarsonemus latus infesting Jatropha curcas in Indonesia
}

\author{
RETNO DYAH PUSPITARINI ${ }^{\vee}$, AMINUDIN AFANDHI, ITO FERNANDO \\ Department of Plant Pests and Diseases, Faculty of Agriculture, Universitas Brawijaya, Jl. Veteran, Malang 65145, East Java, Indonesia. \\ Tel.: +62-341-5758439, `email: retnodyah@ub.ac.id
}

Manuscript received: 11 May 2021. Revision accepted: 11 June 2021.

\begin{abstract}
Puspitarini RD, Afandhi A, Fernando I. 2021. Evaluation of indigenous fungal entomopathogens and aqueous leaf extract of Annona muricata against Polyphagotarsonemus latus infesting Jatropha curcas in Indonesia. Biodiversitas 22: 2648-2655. The broad mite Polyphagotarsonemus latus (Banks) (Acari: Tarsonemidae) has been known to cause a great deal of injury on Jatropha curcas (L.) plantation in Indonesia. Isolation of indigenous fungal entomopathogens from rhizosphere soils, followed by pathogenicity assay was conducted to find an effective isolate for controlling P. latus. Additionally, the potential combination of the selected isolate and soursop (Annona muricata L.) aqueous leaf extract (SLE) was investigated. A total of 24 isolates were obtained by using the insect bait method. Four fungal isolates, namely Paecilomyces sp. 1., Lecanicillium sp., Beauveria sp., and Fusarium sp. 1, showed high conidial viability and were chosen as representatives to assess their pathogenicity against P. latus. Among the tested isolates, Beauveria sp. which had the highest conidial viability among the tested isolates, needed a shorter period to completely kill the tested mites. However, the compatibility test revealed the deleterious effect of SLE on Beauveria sp. SLE at all concentrations showed a very toxic effect on the fungus, therefore the two must be applied separately. Our results provide useful information on the effectiveness of indigenous entomopathogenic fungi Beauveria sp. and aqueous leaf extract of $A$. muricata as an alternative tool to control the broad mite $P$. latus on the $J$. curcas plantation.
\end{abstract}

Keywords: Beauveria, insect bait method; Jatropha curcas, Polyphagotarsonemus latus, rhizosphere soils

\section{INTRODUCTION}

Renewable biofuels derived from agricultural biomass are much needed as the global supply of fossil fuels is in crisis (Baral et al. 2020). Among numerous biomass crops, Jatropha curcas (L.) represents a promising candidate, and therefore a lot of researches has been conducted to maximize its exploitation (Sidibe et al. 2020). Due to its hardiness and adaptability to wide agroclimatic conditions, $J$. curcas is cultivated throughout the world (Ntaribi and Paul 2018). In Indonesia, J. curcas oil is one of the leading non-petroleum sources of biodiesel, and its plantation is growing progressively (Silitonga et al. 2011). However, during field observation at J. curcas plantations in Central Java, it was observed that phytophagous mites severely attacked several plants. Nearly 4,000 mites per leaf were found that consisting mainly of three species, namely Tetranychus sp. (Tetranychidae), Brevipalpus sp. (Tenuipalpidae), and Polyphagotarsonemus latus (Banks) (Tarsonemidae). Amongst, P. latus was found to be ubiquitous and responsible for most of the damage. Thus, this problem must be addressed, and a proper control strategy should be established quickly.

The mite $P$. latus, also known as the broad mite, is an important pest with global distribution in tropical and subtropical regions (Weintraub et al. 2003). More than 60 different plant families are registered as its host (Gerson 1992). A recent study indicated that $P$. latus was the most abundant mite species inhabiting $J$. curcas (Lofego et al. 2013), and become a potential pest of the plant (Rosado et al. 2014, 2015). In J. curcas, the mite infestation usually begins in the shoots and the mite population resides in the lower leaf surfaces. The feeding of $P$. latus causes the leaves to become smaller with a leathery texture, twisted edges, and glassy appearance on the abaxial surface. Additionally, injured new leaves and buds become distorted, eventually, flowers are also malformed or fail to develop (Sarmento et al. 2011).

Due to the heavy infestation of mites, synthetic acaricides have become the conventional practice and perceived to be the cornerstones of an effective control method (van Leeuwen et al. 2015). The repeated use of acaricides is dangerous as they possess indirect hazardous effects on non-target organisms, among other issues (Mills et al. 2016; Meftaul et al. 2020). Consequently, ecofriendly natural acaricides are increasingly needed. Since a decade ago, the ability of fungal entomopathogens in pest control has been explored, and they have become one of the prime biological agents to manage phytophagous mite populations (Mascarin et al. 2019). It has been reported that entomopathogenic fungi can also be used synergistically with botanical acaricides, and their bio-efficacy is bolstered when compatibility is achieved (Hernández et al. 2012). In perspective, the combined application of fungal entomopathogens with botanical pesticides may provide a more powerful tool for pest management strategy (Ribeiro et al. 
2012). Plant-derived acaricides themselves are good candidates for mite control in integrated pest management (IPM) (Venzon et al. 2008; de Assis et al. 2011). Therefore, the discovery of new effective entomopathogenic fungi and botanical acaricide is necessary to suppress the phytophagous mite populations. Given the potential economic damage caused by $P$. latus on $J$. curcas, the present study attempts to find an effective indigenous entomopathogenic fungus, elucidate its efficacy against the mite, and evaluate its acaricidal activity plant extract derived from soursop leaves (Annona muricata L.). Subsequently, the effects of co-formulation between the plant extract with entomopathogenic fungus were determined. Entomopathogenic fungi were isolated from the rhizosphere soils of $P$. latus-infested crops.

\section{MATERIALS AND METHODS}

\section{Mite rearing}

The mite P. latus was obtained from infested $J$. curcas during field investigations. Infested leaves were harvested and put in a cooler box. The mites were then brought to the Plant Pests Laboratory, Department of Plant Pests and Diseases, University of Brawijaya, Indonesia. In the laboratory, mites were reared on leaves of Citrus sp. and placed in an 'arena'. To make an arena, a water-soaked sponge $(5 \mathrm{~cm} \times 5 \mathrm{~cm} \times 1.5 \mathrm{~cm})$ was placed inside a Petri dish $(\mathrm{d}=9 \mathrm{~cm})$. The sponge was covered with moistened cotton, and then, a citrus leaf was placed over the cotton with the abaxial surface facing up (Martins et al. 2016). Regular watering was done to maintain the humidity in Petri dishes, keep the leaf in turgid condition, and prevent the desiccation of the mites (Puspitarini et al. 2021). The rearing was performed under laboratory conditions at $25 \pm$ $1{ }^{\circ} \mathrm{C}$, RH $68 \pm 2 \%$, and photoperiod of L12:D12 h. Mites were also maintained in a greenhouse on citrus plants aged 1-2 years.

\section{Collection of rhizosphere soil samples}

Soil samples were collected from two different host plants, namely Citrus sp. and J. curcas. For each host plant, four different fields, located in Malang and Batu (East Java, Indonesia), were selected as sampling sites (Table 1). Each field comprised of 10 sampling units, located using a diagonal pattern. Rhizosphere soil was taken at $10-15 \mathrm{~cm}$ depth with a garden spade. The soil sample was then placed into a plastic bag and kept in an airtight cooler box. The garden spade was cleaned with $70 \%$ ethanol after being used to minimize the cross-contamination of fungal entomopathogens among the sampling sites. A total of 80 soil samples were collected as the source of fungal entomopathogens.

\section{Isolation of fungal entomopathogens from rhizosphere soils}

Isolation was based on the insect bait method by using the fourth instar larvae of Tenebrio molitor L. (Coleoptera: Tenebrionidae) (Sharma et al. 2018). Briefly, $500 \mathrm{~g}$ of sieved soil was put in a plastic tray and remoistened. After that, 25 T. molitor larvae were placed in the tray. Trays were kept under laboratory conditions and covered with a black cloth to achieve a complete darkness condition. During two weeks of the incubation period, insect cadavers were observed daily. The obtained cadavers were then washed with $1 \%$ sodium hypochlorite $(\mathrm{NaOCl})$ for three minutes and rinsed three times with distilled water. The clean insect cadavers were cultured on Sabouraud dextrose agar with yeast (SDAY) and incubated under the same aforementioned laboratory conditions for 7 days. Subculturing was done to obtain a pure fungal culture. In addition, all the isolated fungi were subjected to Koch's postulates to ascertain their pathogenicity.

\section{Fungal identification}

The identification of the obtained entomopathogenic fungi was based on their morphological characteristics using a taxonomic key as described by Domsch et al. (2007).

\section{Fungal conidia viability assay}

Conidia viability was tested as the primary criteria determining the selection of entomopathogenic fungi used for the further assay. Initially, each isolate was grown on SDAY in Petri dishes for 7 days until conidia were produced (Shi and Feng 2004). Conidia were further inoculated into potato dextrose broth (Oliveira et al. 2015). Chloramphenicol $(1 \%)$ was added to the media to hinder contamination from other microorganisms. Before being used, conidial concentration was adjusted to $10^{7}$ conidia/ml using a hemocytometer. The viability assay was conducted as per Herlinda (2010) using potato dextrose agar (PDA) as the medium.

Fungal pathogenicity assay against $\boldsymbol{P}$. latus

Treatments of this assay consisted of the four selected fungal isolates obtained from the previous assay, and control containing distilled water alone. Each treatment was replicated seven times. Fungal conidia concentration was adjusted to $10^{7}$ conidia $/ \mathrm{ml}$, after that a leaf disc of citrus (approximately $3 \mathrm{~cm}$ x $3 \mathrm{~cm}$ ) was sprayed with each treatment at a $1 \mathrm{ml}$ rate per leaf. The application was done manually using a calibrated hand sprayer. Ten adults of $P$. latus aged 0-24 h, that were initially placed into the arena, were allowed to feed on the treated-leaf disc. To obtain mites of the same age, individuals that enter the last quiescent stage were arbitrarily taken from the stock cultures and transferred into a given arena.

Table 1. Location of the sampling sites

\begin{tabular}{lcl}
\hline Host plant & Site & Location \\
\hline Citrus sp. & 1 & $7^{\circ} 49^{\prime} 55.86^{\prime \prime} \mathrm{S}, 112^{\circ} 31^{\prime} 39.46^{\prime \prime} \mathrm{E}$ \\
& 2 & $7^{\circ} 50^{\prime} 7.81^{\prime \prime} \mathrm{S}, 112^{\circ} 31^{\prime} 31.79^{\prime \prime} \mathrm{E}$ \\
& 3 & $7^{\circ} 54^{\prime} 42.88^{\prime \prime} \mathrm{S}, 112^{\circ} 32^{\prime} 25.25^{\prime \prime} \mathrm{E}$ \\
& 4 & $7^{\circ} 55^{\prime} 2.99^{\prime \prime} \mathrm{S}, 112^{\circ} 34^{\prime} 8.42^{\prime \prime} \mathrm{E}$ \\
Jatropha curcas & 5 & $8^{\circ} 0^{\prime} 21.22^{\prime \prime} \mathrm{S}, 112^{\circ} 46^{\prime} 13.31^{\prime \prime} \mathrm{E}$ \\
& 6 & $8^{\circ} 4^{\prime} 0.95^{\prime \prime} \mathrm{S}, 112^{\circ} 48^{\prime} 51.51^{\prime \prime} \mathrm{E}$ \\
& 7 & $8^{\circ} 7^{\prime} 44.63^{\prime \prime} \mathrm{S}, 112^{\circ} 45^{\prime} 4.37^{\prime \prime} \mathrm{E}$ \\
& 8 & $8^{\circ} 3^{\prime} 22.12^{\prime \prime} \mathrm{S}, 112^{\circ} 44^{\prime} 5.7^{\prime \prime} \mathrm{E}$ \\
\hline
\end{tabular}


Thereafter, mites that emerged on the same day were taken for the experiment. Following the treatments, mortality was checked daily during 6 days of the observation period (Martins et al. 2016). Test mites were assumed dead if there was no movement of the appendages when being touched with a brush. Mortality was then calculated and expressed in percentage.

\section{Collection and extraction of soursop leaves}

The soursop (A. muricata) leaves were collected from the vicinity of the University of Brawijaya, Indonesia. Collected leaves were cleaned under running tap water and were drained thoroughly. For extraction, $100 \mathrm{~g}$ of the leaf along with $100 \mathrm{ml}$ of sterilized distilled water were mixed using an electric blender and subsequently were shaken overnight at $220 \mathrm{rpm}$. The suspension was filtered with Whatman filter paper, and the clean filtrate was kept in a sterilized glass bottle. Soursop aqueous leaf extract (SLE) was then stored at a $4^{\circ} \mathrm{C}$ refrigerator for further experiments. Three concentrations that were $0.5,1$, and $1.5 \%$ were prepared from the stock solution using the addition of an appropriate amount of distilled water.

\section{Compatibility assessment between Beauveria sp. and SLE}

Entomopathogenic fungus Beauveria sp. was the most virulence isolate, hence it was used as the sole fungal isolate for this assay. To evaluate the compatibility between botanical acaricide with the fungus, SLE at various concentrations was incorporated into the PDA following the procedure described by Depieri et al. (2005). Beauveria sp. inoculum was prepared by suspending fungal spores in a falcon tube containing $10 \mathrm{ml}$ of distilled water with $0.02 \%$ of Tween 20 . The tube was centrifuged at 3,000 rpm for $5 \mathrm{~min}$ to separate the conidia. The conidia pellet was mixed with distilled water and the conidia concentration was standardized into three levels $\left(10^{4}, 10^{6}\right.$, and $10^{8}$ conidia/ml). An aliquot of each solution was then added into a petri dish with a PDA medium incorporating a given concentration of SLE. A PDA medium without SLE was considered as the control. In total, 12 treatments and 4 replicates were included. During 6 days of the incubation period, the fungal vegetative growth, conidial production, and conidial viability were observed and calculated (Depieri et al. 2015). Compatibility was then determined by calculation of $\mathrm{T}$ factor, $\mathrm{T}=[20(\mathrm{VG})+80(\mathrm{SP})] / 100$, where $\mathrm{VG}$ is relative vegetative growth and $\mathrm{SP}$ is sporulation values compared to the control. The $\mathrm{T}$ values from $0-30$ indicate that the botanical acaricide is considered as very toxic; from 31-45 as toxic; from 46-60 as moderately toxic; and $>60$ represent that botanical acaricide is considered compatible with the fungal entomopathogen.

Toxicity bioassay of Beauveria sp. and SLE against $\boldsymbol{P}$. latus

The bioefficacy of Beauveria sp. and SLE against $P$. latus was assessed separately. The toxicity assay consisted of five replicates per treatment. Totally seven treatments consist of three different levels of SLE concentration $(0,1$, and $1.5 \%$ ), three different levels of Beauveria sp. conidia density $\left(10^{4}, 10^{6}\right.$, and $10^{8}$ conidia/ml), and control containing distilled water alone. The application was conducted similarly to the previous method described earlier in fungal pathogenicity assay.

\section{Statistical analysis}

All assays were designed in a completely randomized design. Obtained data were initially subjected to the Shapiro-Wilk test to validate that the normality assumption was met. The data were then subjected to analysis of variance (ANOVA) and the mean values were compared by using Duncan's test at $\mathrm{P}<0.05$. R statistics was employed as the software.

\section{RESULTS AND DISCUSSION}

\section{Fungal entomopathogens isolated from Jatropha curcas and Citrus sp. rhizosphere soils and their conidial viability}

In this study, rhizosphere soil was chosen as the source of fungal entomopathogens. It is known that soil is a natural reservoir of entomopathogenic fungi. Results showed that a total of 24 different fungal isolates were isolated from the collected rhizosphere soils. These fungal isolates belong to ten genera, namely Metarhizium sp., Aspergillus sp., Fusarium sp., Penicillium sp., Cladosporium sp., Paecilomyces sp., Lecanicillium sp., Acremonium sp., and Beauveria sp. (Table 2). The entomopathogenic fungus Metarhizium was the most common in the sampled areas, both in J. curcas or Citrus sp. plantations. Several studies indicate that Metarhizium is the most commonly found fungus in agricultural fields (Quesada-Moraga et al. 2007; Sánchez-Peña et al. 2011). Metarhizium compared with the other fungal entomopathogens, is more tolerant to pesticides therefore it persisted in cultivated habitats (Vänninen et al. 2000; Bruck 2004). It was also observed that pesticides regularly applied the selected fields during the growing season.

The sampled areas were selected because of the prevalence of $P$. latus infestation in those locations, therefore our first hypothesize was that the indigenous fungal entomopathogens act as the natural enemies of $P$. latus in the field. Moreover, their presence might be considered as an environmental service and potentially suppress the $P$. latus population. However, the efficacy of each isolate is certainly varied depending on individual innate virulence and genetic variability (Xiao et al. 2012). One of the main parameters used to determine the virulence of entomopathogenic fungi is conidial viability (Faria et al. 2015). Out of 24 isolates, Paecilomyces sp. 1., Lecanicillium sp., Beauveria sp., and Fusarium sp. 1, were the isolates with the relatively higher conidial viability ranging from 39.04 to $55.3 \%$ (Table 1). This result is in agreement with previous works reporting that conidial viability is strongly species- and strain-specific (Herlinda 2010; Xavier-Santos et al. 2011). Moreover, Jin et al. (1992) suggested that propagules with a slow-germinating capability are not efficiently being utilized as biocontrol agents. Therefore, only the four isolates were tested for their pathogenicity against $P$. latus. Although Metarhizium sp. was the most prevalent species, it had a low conidia viability and therefore not used in the pathogenicity assay. 


\section{Beauveria sp. has higher pathogenicity to $P$. latus} compared with the other fungal entomopathogens

All entomopathogenic fungi caused mortality of $P$. latus since the first day of observation, and the lethal effects were more profound afterward (Table 3). Beauveria sp. exhibited the highest control efficacy causing complete mortality of adults $P$. latus on the fourth day of observation. This result was consistent with the results of the conidial viability assay which showed that Beauveria sp. had greater conidial viability. The ability of Beauveria sp. to kill phytophagous mites has been addressed by a myriad of researches, such as against the two-spotted spider mite Tetranychus urticae Koch (Wu et al. 2016), citrus rust mite Phyllocoptruta oleivora (Ashmead) (Alves et al. 2005), and false spider mite Brevipalpus phoenicis (Geijskes) (RossiZalaf and Alves 2006). Similarly, Nugroho and Ibrahim (2004) found that Beauveria bassiana significantly caused the highest mortality rate on $P$. latus. In addition, it was also observed that there was a large variation in the mite mortality among the tested entomopathogens ( $B$. bassiana, Metarhizium anisopliae, and Isaria fumosorosea) which was in accordance with our results.

\section{Compatibility of SLE with Beauveria sp.}

Proper understanding of the compatibility of fungal entomopathogens with other pest control techniques is necessary to maximize their potential or hinder the unwanted contradictory effects. In all tested concentrations, aqueous extract derived from soursop leaves (SLE) only slightly reduced the vegetative growth (Table 4) and conidiogenesis (Table 5) of Beauveria sp. The decreases in the mycelial growth and conidia production of entomopathogenic fungi by botanical pesticides have been demonstrated by several researchers (Mohan et al. 2007; Jamali et al. 2021). Ribeiro et al. (2012) found that bioactive compounds of botanical pesticides may directly affect the growth and development of entomopathogenic fungi, or indirectly influence the $\mathrm{pH}$ of the culture medium. However, the effect of botanical pesticides on entomopathogenic fungi is strongly dependent on the concentrations and formulation used and the quantitative and qualitative composition of bioactive compounds contained in the products (Forim et al. 2010; Diniz et al. 2020). Additionally, the genetic profile of each species or strain of entomopathogenic fungus also determines its susceptibility in response to botanical pesticide exposure (Mohan et al. 2007).
Table 2. Fungal entomopathogen isolates found in rhizosphere soil of Citrus sp. and Jatropha curcas by using the insect bait method, and their conidial viability after incubation for $24 \mathrm{~h}$

\begin{tabular}{|c|c|c|}
\hline Host plants & Fungal isolate & $\begin{array}{c}\% \text { Conidial } \\
\text { viability }\end{array}$ \\
\hline \multirow{13}{*}{ Citrus sp. } & Metarhizium sp. 1 & 27.78 \\
\hline & Metarhizium sp. 5 & 22.83 \\
\hline & Metarhizium sp. 8 & 21.59 \\
\hline & Aspergillus sp. 1 & 24.19 \\
\hline & Aspergillus sp. 2 & 14.29 \\
\hline & Aspergillus sp. 4 & 18.74 \\
\hline & Fusarium sp. 3 & 14.20 \\
\hline & Penicillium sp. 1 & 27.08 \\
\hline & Cladosporium sp. 2 & 19.98 \\
\hline & Paecylomyces sp. & 29.41 \\
\hline & Acremonium sp. & 26.13 \\
\hline & Metarhizium sp. 3 & 14.21 \\
\hline & Metarhizium sp. 4 & 40.20 \\
\hline \multirow[t]{11}{*}{ Jatropha curcas } & Metarhizium sp. 6 & 12.38 \\
\hline & Metarhizium sp. 7 & 39.044 \\
\hline & Fusarium sp. 4 & 35.08 \\
\hline & Penicillium sp. 2 & 15.13 \\
\hline & Cladosporium sp. 1 & 23.53 \\
\hline & Lecanicillium sp. 1 & 41.70 \\
\hline & Beauveria sp. & 55.35 \\
\hline & Fusarium sp. 2 & 23.30 \\
\hline & Trichoderma sp. & 17.37 \\
\hline & Aspergillus sp. 3 & 25.64 \\
\hline & Fusarium sp. 1 & 27.36 \\
\hline
\end{tabular}

Table 4. Mean of colony diameter of Beauveria sp. on PDA supplemented with different concentration of SLE at 6 days after inoculation

\begin{tabular}{|c|c|c|}
\hline Treatments & $\begin{array}{c}\text { Colony } \\
\text { diameter } \\
(\mathrm{cm} \pm \mathrm{SD})\end{array}$ & $\begin{array}{c}\text { Reduction at } 6 \\
\text { DAI }(\%)\end{array}$ \\
\hline Beauveria sp. $10^{4}$ and SLE 0 & $4.73 \pm 0.74$ & - \\
\hline Beauveria sp. $10^{6}$ and SLE 0 & $4.75 \pm 0.13$ & - \\
\hline Beauveria sp. $10^{8}$ and SLE 0 & $4.83 \pm 0.73$ & - \\
\hline Beauveria sp. $10^{4}$ and SLE 0.5 & $3.70 \pm 0.30$ & 0.22 \\
\hline Beauveria sp. $10^{6}$ and SLE 0.5 & $4.40 \pm 0.23$ & 0.07 \\
\hline Beauveria sp. $10^{8}$ and SLE 0.5 & $4.73 \pm 0.85$ & 0.02 \\
\hline Beauveria sp. $10^{4}$ and SLE 1 & $3.60 \pm 1.07$ & 0.24 \\
\hline Beauveria sp. $10^{6}$ and SLE 1 & $3.83 \pm 0.19$ & 0.19 \\
\hline Beauveria sp. $10^{8}$ and SLE 1 & $4.50 \pm 0.23$ & 0.07 \\
\hline Beauveria sp. $10^{4}$ and SLE 1.5 & $3.18 \pm 0.24$ & 0.33 \\
\hline Beauveria sp. $10^{6}$ and SLE 1.5 & $3.80 \pm 0.45$ & 0.20 \\
\hline Beauveria sp. $10^{8}$ and SLE 1.5 & $4.43 \pm 0.76$ & 0.08 \\
\hline
\end{tabular}

Note: Beauveria sp. concentration was in conidia/ml and SLE concentration was in \%. Means were not statistically different among the treatments.

Table 3. Mean mortality (\%) of adult $P$. latus after the application of fungal entomopathogen isolates

\begin{tabular}{lllllll}
\hline \multirow{2}{*}{ Fungal entomopathogens } & \multicolumn{5}{c}{ Day(s) after application } \\
\cline { 2 - 7 } & \multicolumn{1}{c}{$\mathbf{1}$} & $\mathbf{2}$ & $\mathbf{3}$ & $\mathbf{4}$ & $\mathbf{5}$ & $\mathbf{6}$ \\
\hline Control (distilled water) & $0.00 \mathrm{a}$ & $0.00 \mathrm{a}$ & $0.00 \mathrm{a}$ & $0.00 \mathrm{a}$ & $0.00 \mathrm{a}$ & $0.00 \mathrm{a}$ \\
Fusarium sp. 1 & $8.57 \mathrm{~b}$ & $31.43 \mathrm{~b}$ & $50.00 \mathrm{~b}$ & $80.00 \mathrm{~b}$ & $97.14 \mathrm{~b}$ & $100.00 \mathrm{~b}$ \\
Paecilomyces sp. 1 & $14.29 \mathrm{bc}$ & $34.29 \mathrm{bc}$ & $64.29 \mathrm{c}$ & $84.29 \mathrm{~b}$ & $98.57 \mathrm{~b}$ & $100.00 \mathrm{~b}$ \\
Lecanicillium sp. 1 & $17.14 \mathrm{c}$ & $42.86 \mathrm{c}$ & $67.14 \mathrm{c}$ & $88.57 \mathrm{~b}$ & $97.14 \mathrm{~b}$ & $100.00 \mathrm{~b}$ \\
Beauveria sp. & $37.14 \mathrm{~d}$ & $80.00 \mathrm{~d}$ & $95.71 \mathrm{~d}$ & $100.00 \mathrm{~b}$ & $100.00 \mathrm{~b}$ & $100.00 \mathrm{~b}$ \\
\hline
\end{tabular}

Note: The concentration of fungal entomopathogens was $10^{7}$ conidia/ml. Means followed by different letters on the same row indicate significant differences (ANOVA followed by Duncan's test at $\mathrm{P}<0.05$ ) 
Spore germination has a pivotal role in determining the effectiveness of entomopathogenic fungi under field conditions, and laboratory assessment is primarily undertaken to elucidate the effect of products on conidial viability. In the present study, it was observed that SLE showed a deleterious effect on Beauveria sp. germination. The reduction of conidial viability was significant and depended on concentration, with SLE at $1.5 \%$ greatly suppressed the conidia germination (Table 6). Soursop extract has been known to contain alkaloids, flavonoids, triterpenoids, and acetogenins (Ravaomanarivo et al. 2014). Those secondary metabolites found in SLE may serve as fungi toxic compounds against Beauveria sp. A recent study indicates that some plant derivatives, such as alkaloids, although confer pesticidal activities for pest control, also negatively affect fungal entomopathogens (Ribeiro et al. 2012).

Although the effect of SLE on mycelial growth and conidiogenesis was not statistically different, the $T$ value indicated that SLE at all concentrations was not compatible with Beauveria sp., and was very toxic (Table 7). A higher concentration of SLE elicited a lower T value, and it was ranged as low as 1.79 (Beauveria sp. $10^{4}$ conidia/ml with SLE at $1.5 \%$ ) to the highest of only 3.52 (Beauveria sp. $10^{8}$ conidia/ml with SLE at $0.5 \%$ ). Supporting this statement, Saharayaj et al. (2011) reported that among the five tested plant extracts used in their study, only Annona extract showed significant inhibition on the tested fungal entomopathogens, especially B. bassiana, I. fumosorosea, and Lecanicillium lecanii. Hence, it clearly indicates that Annona extract is incompatible with entomopathogenic fungus. These results are similar to those reported by Hirose et al. (2001), who reported a significant reduction in spore germination of $B$. bassiana when combined with neem oil at $2 \%$. We suggest that the combined application of plant extract and entomopathogenic fungi must be avoided if contradictory interactions were detected.

\section{Acaricidal activity of SLE on $\boldsymbol{P}$. latus is comparable with Beauveria sp.}

Soursop is traditionally employed as biopesticidal agents and topical insect repellents throughout the world (Moghadamtousi et al. 2015). A plethora of researches prove the anti-pest feature of the aqueous extract of soursop such as to control stored product pests, aphids, thrips, lepidopteran larvae, and mosquito (Leatemia and Isman, 2004; Adeoye and Ewete, 2010; Asmanizar et al. 2012; Ravaomanarivo et al. 2014; Ribeiro et al. 2014). Nonetheless, to date, the application of soursop extract on phytophagous mites is still obscure, especially on $P$. latus. Considering the local abundance of this plant in Indonesia, we attempted to exploit the plant as a promising candidate for botanical acaricide. In this present work, the acaricidal activity of SLE and Beauveria sp. against P. latus was tested separately at various concentrations (because of their incompatibility). Results of the toxicity assay evidenced the potent acaricidal activity of SLE. On the last day of observation, SLE at all concentrations gave higher mortality on $P$. latus than the Beauveria sp. at $10^{4}, 10^{6}$ conidia/ml (Table 8 ).
Table 5. Average amount of Beauveria sp. conidia on PDA supplemented with different concentration of SLE at 6 days after inoculation

\begin{tabular}{|c|c|c|}
\hline \multirow[b]{2}{*}{ Treatments } & \multicolumn{2}{|c|}{ Conidia amount } \\
\hline & $\begin{array}{c}\left(\begin{array}{c}x \\
10^{8} / \mathrm{ml} \pm \\
\text { SD) }\end{array}\right.\end{array}$ & $\begin{array}{c}\text { Reduction } \\
(\%)\end{array}$ \\
\hline Beauveria sp. $10^{4}$ and SLE 0 & $2.51 \pm 0.32$ & - \\
\hline Beauveria sp. $10^{6}$ and SLE 0 & $2.99 \pm 0.21$ & - \\
\hline Beauveria sp. $10^{8}$ and SLE 0 & $5.15 \pm 1.55$ & - \\
\hline Beauveria sp. $10^{4}$ and SLE 0.5 & $2.20 \pm 0.76$ & 0.12 \\
\hline Beauveria sp. $10^{6}$ and SLE 0.5 & $2.64 \pm 0.57$ & 0.12 \\
\hline Beauveria sp. $10^{8}$ and SLE 0.5 & $3.22 \pm 1.04$ & 0.37 \\
\hline Beauveria sp. $10^{4}$ and SLE 1 & $2.08 \pm 0.72$ & 0.17 \\
\hline Beauveria sp. $10^{6}$ and SLE 1 & $2.54 \pm 1.17$ & 0.15 \\
\hline Beauveria sp. $10^{8}$ and SLE 1 & $2.74 \pm 0.71$ & 0.47 \\
\hline Beauveria sp. $10^{4}$ and SLE 1.5 & $1.44 \pm 0.45$ & 0.43 \\
\hline Beauveria sp. $10^{6}$ and SLE 1.5 & $2.34 \pm 0.42$ & 0.22 \\
\hline Beauveria sp. $10^{8}$ and SLE 1.5 & $2.69 \pm 0.14$ & 0.48 \\
\hline
\end{tabular}

Note: Beauveria sp. concentration was in conidia/ml and SLE concentration was in \%. Means were not statistically different among the treatments

Table 6. Mean of conidia viability of Beauveria sp. on PDA supplemented with different concentration of SLE

\begin{tabular}{lll}
\hline \multirow{2}{*}{ Treatments } & Conidia viability & \\
\cline { 2 - 3 } & $(\boldsymbol{\%} \pm$ SD) & $\begin{array}{l}\text { Reduction } \\
(\%)\end{array}$ \\
\hline Beauveria sp. $10^{4}$ and SLE 0 & $89.73 \pm 4.86 \mathrm{~cd}$ & - \\
Beauveria sp. $10^{6}$ and SLE 0 & $94.88 \pm 0.49 \mathrm{~d}$ & - \\
Beauveria sp. $10^{8}$ and SLE 0 & $95.97 \pm 1.64 \mathrm{~d}$ & - \\
Beauveria sp. $10^{4}$ and SLE 0.5 & $73.38 \pm 6.04 \mathrm{abc}$ & 0.18 \\
Beauveria sp. $10^{6}$ and SLE 0.5 & $83.47 \pm 5.94 \mathrm{bcd}$ & 0.12 \\
Beauveria sp. $10^{8}$ and SLE 0.5 & $87.57 \pm 1.13 \mathrm{bcd}$ & 0.09 \\
Beauveria sp. $10^{4}$ and SLE 1 & $69.28 \pm 2.63 \mathrm{ab}$ & 0.23 \\
Beauveria sp. $10^{6}$ and SLE 1 & $81.43 \pm 2.63 \mathrm{bcd}$ & 0.14 \\
Beauveria sp. $10^{8}$ and SLE 1 & $86.03 \pm 5.56 \mathrm{bcd}$ & 0.10 \\
Beauveria sp. $10^{4}$ and SLE 1.5 & $58.62 \pm 8.28 \mathrm{a}$ & 0.35 \\
Beauveria sp. $10^{6}$ and SLE 1.5 & $75.67 \pm 3.09 \mathrm{ab}$ & 0.20 \\
Beauveria sp. $10^{8}$ and SLE 1.5 & $83.55 \pm 3.19 \mathrm{ab}$ & 0.13 \\
\hline
\end{tabular}

Note: Beauveria sp. concentration was in conidia/ml and SLE concentration was in \%. Means followed by different letters on the same row indicate significant differences (ANOVA followed by Duncan's test at $\mathrm{P}<0.05$ )

Table 7. SLE compatibility classification with the entomopathogenic fungus Beauveria sp.

\begin{tabular}{lcl}
\hline Treatments & T & Classification \\
\hline Beauveria sp. $10^{4}$ and SLE 0.5 & 2.50 & Very toxic \\
Beauveria sp. $10^{6}$ and SLE 0.5 & 2.99 & Very toxic \\
Beauveria sp. $10^{8}$ and SLE 0.5 & 3.52 & Very toxic \\
Beauveria sp. $10^{4}$ and SLE 1 & 2.38 & Very toxic \\
Beauveria sp. $10^{6}$ and SLE 1 & 2.80 & Very toxic \\
Beauveria sp. $10^{8}$ and SLE 1 & 3.09 & Very toxic \\
Beauveria sp. $10^{4}$ and SLE 1.5 & 1.79 & Very toxic \\
Beauveria sp. $10^{6}$ and SLE 1.5 & 2.63 & Very toxic \\
Beauveria sp. $10^{8}$ and SLE 1.5 & 3.04 & Very toxic \\
\hline
\end{tabular}

Note: $\mathrm{T}$ value was calculated from the formula proposed by Depieri et al. (2005) 
Table 8. Toxicity of Beauveria sp. and SLE against $P$. latus as represented by the mean of adult mortality at 6 days after application

\begin{tabular}{ll}
\hline Treatments & Mortality $(\% \pm$ SD $)$ \\
\hline Control & $0.00 \pm 0.00 \mathrm{a}$ \\
Beauveria sp. $10^{4}$ conidia/ml & $74.00 \pm 2.45 \mathrm{~b}$ \\
Beauveria sp. $10^{6}$ conidia/ml & $76.00 \pm 9.27 \mathrm{~b}$ \\
Beauveria sp. $10^{8}$ conidia/ml & $100.00 \pm 8.60 \mathrm{c}$ \\
SLE $0.5 \%$ & $94.00 \pm 13.04 \mathrm{c}$ \\
SLE $1 \%$ & $98.00 \pm 8.94 \mathrm{c}$ \\
SLE $1.5 \%$ & $100.00 \pm 4.47 \mathrm{c}$ \\
\hline
\end{tabular}

Note: Means followed by different letters on the same rows indicate significant differences (ANOVA followed by Duncan's test at $\mathrm{P}<0.05$ )

The high toxicity of SLE reported in this study was in accordance with a previous study (Ravaomanarivo et al. 2014), that under a similar extraction method, the application of an aqueous extract of soursop on two dipteran species showed $\mathrm{LC}_{50}$ values ranged from $1-5 \%$ for adults and only $0.5-1 \%$ for larvae. Acaricidal activity of soursop was attributed to the various bioactive compound groups found in the plant extract such as flavonoids, fatty acids, alkaloids, and acetogenins (Bermejo et al. 2005; Das et al. 2007).

Alkaloids found in soursop extract have been known to inhibit the active site of acetylcholinesterase, a key enzyme in the nervous system of arthropods (Scott et al. 2008). Plant fatty acids also possess acaricidal activities through a multitude of direct mechanisms or may augment the toxicity of other bioactive compounds (Ravaomanarivo et al. 2014). Acetogenins which are specific to the Annonaceae family, also exhibit diverse biological activities, including act as stomach poisons identical to the rotenone's mode of action (de Cássia Seffrin et al. 2010), or serve as a contact poison and antifeedant (Leatemia and Isman 2004; Maryam et al. 2004; Isman 2006).

Regarding the Beauveria sp., one of the determining factors in the infection process of Beauveria sp. on its host is the initial number of inoculums. The higher conidia concentration may increase the number of adhered conidia in the host's cuticle. After germinating, the conidia penetrate the host cuticle. The fungus then secretes various enzymes to counter the immune system of its host (HarithFadzilah et al. 2021). Additionally, Chandler (2007) observed that the fungus also produces secondary metabolites such as oosporeins, tenellins, isarolides, beauverolides, and beauvericin which are toxic to the arthropod cells.

This study provides useful information on the effectiveness of indigenous entomopathogenic fungi Beauveria sp. and aqueous leaf extract of soursop as an alternative tool to control the broad mite P. latus. Their application can be implemented in the IPM-based management strategy. Moreover, these control strategies do not require high-tech machinery, and thus are cost-efficient and easily adopted by smallholder farmers, especially in developing countries. Nevertheless, field experiments are necessary to ascertain their efficacy under natural conditions. In conclusion, 24 fungal entomopathogens belong to ten genera were successfully isolated from rhizosphere soils of $J$. curcas and Citrus sp. Based on the conidial viability assessment, four isolates, Paecilomyces sp. 1., Lecanicillium sp., Beauveria sp., and Fusarium sp. 1 , were selected as potential candidates. There is a positive relationship between fungal conidial viability and pathogenicity as indicated in Beauveria sp., which in turn confirms the general theory of which isolate selection could be based solely on the percentage of spore germination. Further experiments revealed that even the lowest concentration of SLE had adverse effects toward Beauveria sp., thus SLE was not compatible upon co-application with the fungus. The result of toxicity bioassay indicated promising acaricidal activities of Beauveria sp. and SLE for the management of broad mite P. latus.

\section{ACKNOWLEDGEMENTS}

The authors would like to thank our colleagues Hagus Tarno (Department of Plant Pests and Diseases, University of Brawijaya, Indonesia) and Shubhra Singh (Patanjali Research Institute, India) for their linguistic assistance during the preparation of this manuscript.

\section{REFERENCES}

Adeoye OT, Ewete FK. 2010. Potentials of Annona muricata Linnaeus (Annonaceae) as a botanical insecticide against Callosobruchus maculatus Fabricius (Coleoptera: Bruchidae). J Agric Forest Soc Sci 8 (2): 147-151. DOI: $10.4314 /$ joafss.v8i2.71652

Alves SB, Tamai MA, Rossi L, Castiglioni E. 2005. Beauveria bassiana pathogenicity to the citrus rust mite Phyllocoptruta oleivora. Exp Appl Acrol 37 (1-2): 117-122. DOI: 10.1007/s10493-005-0314-y

Asmanizar, Djamin A, Idris AB. 2012. Evaluation of Jatropha curcas and Annona muricata seed crude extracts against Sitophilus zeamais infesting stored rice. $\mathrm{J}$ Entomol 9 (1): 13-22. DOI: 10.3923/je.2012.13.22

Baral NE, Neupane P, Ale BB, Quiroz-Arita C, Manandhar S, Bradley TH. 2020. Stochastic economic and environmental footprints of biodiesel production from Jatropha curcas Linnaeus in the different federal states of Nepal. Renew Sustain Energy Rev 120, 109619. DOI: 10.1016/j.rser.2019.109619

Bermejo A, Figadere B, Zafra-Polo MC, Barrachina I, Estornell E, Cortes D. 2005. Acetogenins from Annonaceae: recent progress in isolation, synthesis and mechanisms of action. Nat Prod Rep 22 (2): 269-303. DOI: $10.1039 / \mathrm{b} 500186 \mathrm{~m}$

Bruck DJ. 2004. Natural occurrence of entomopathogens in Pacific Northwest nursery soils and their virulence to the black vine weevil, Otiorhynchus sulcatus (F.) (Coleoptera Curculionidae). J Environ Entomol 33: 1335-1343. DOI: 10.1603/0046-225X-33.5.1335

Chandler D. 2017. Basic and applied research on entomopathogenic fungi. In: Lacey L. (eds). Microbial Control of Insect and Mite Pests: From Theory to Practice. Academic Press, Cambridge. DOI: 10.1016/B9780-12-803527-6.00005-6

de Assis CPO, Gondim Jr. MGC, de Siquiera HAA, da Câmara CAG. 2011. Toxicity of essential oils from plants towards Tyrophagus putrescentiae (Schrank) and Suidasia pontifica Oudemans (Acari: Astigmata). J Stor Prod Res 47: 311-315. DOI: 10.1016/j.jspr.2011.04.005

de Cássia Seffrin R, Shikano I, Akhtar Y, Isman MB. 2010. Effects of crude seed extracts of Annona atemoya and Annona squamosa L. against the cabbage looper, Trichoplusia $n i$ in the laboratory and greenhouse. Crop Prot 29: 20-24. DOI: 10.1016/j.cropro.2009.09.003

Das NG, Goswami D, Rabha B. 2007. Preliminary evaluation of mosquito larvicidal efficacy of plant extracts. J Vector Borne Dis 44: 145-148. 
Depieri RA, Martinez SS, Menezes Jr. AO. 2005. Compatibility of the fungus Beauveria bassiana (Bals.) Vuill. (Deuteromycetes) with extracts of neem seeds and leaves and the emulsible oil. Neotrop Entomol 34(4): 601-606. DOI:10.1590/S1519-566X2005000400010

Diniz AG, Barbosa LFS, Santos ACS, de Oliveira NT, da Costa AF, Carneiro-Leão MP, Tiago PV. 2020. Bio-insecticide effect of isolates of Fusarium caatingaense (Sordariomycetes: Hypocreales) combined to botanical extracts against Dactylopius opuntiae (Hemiptera: Dactylopiidae). Biocontrol Sci Technol 30 (4): 384-395. DOI: 10.1080/09583157.2020.1720601

Domsch KH, Gams W, Anderson TH. 2007. Compendium of Soil Fungi, 2nd edn. IHW-Verlag and Verlagsbuchhandlung, Eching. DOI: 10.1111/j.1365-2389.2008.01052 1.x

Faria M, Lopes RB, Souza DA, Wraight SP. 2015. Conidial vigor vs. viability as predictors of virulence of entomopathogenic fungi. J Invertebr Pathol 125: 68-72. DOI: 10.1016/j.jip.2014.12.012

Forim, MR, da Silva MFGF, Cass QB, Fernandes JB, Vieira PC. 2010 Simultaneous quantification of azaridachtin and 3-tigloylazadirachtol in Brazilian seeds and oil of Azadirachta indica: application to quality control and marketing. Anal Methods 2 ( 7): 860-869. DOI: 10.1039/C0ay00008f

Gerson U. 1992. Biology and control of the broad mite, Polyphagotarsonemus latus (Banks) (Acari: Tarsonemidae). Exp Appl Acarol 13: 163-178. DOI: 10.1007/BF01194934

Harith-Fadzilah N, Ghani IA, Hassan M. 2021. Omics-based approach in characterizing mechanisms of entomopathogenic fungi pathogenicity: A case example of Beauveria bassiana. J King Saud Univ Sci 33: 101332. DOI: $10.1016 /$ j.jksus.2020.101332

Herlinda S. 2010. Spore density and viability of entomopathogenic fungal isolates from Indonesia, and their virulence against Aphis gossypi Glover (Homoptera: Aphididae). Trop Life Sci Res 21 (1): 11-19.

Hernández MM, Martínez-Villar E, Peace C, Pérez-Moreno I, Marco V. 2012. Compatibility of the entomopathogenic fungus Beauveria bassiana with flufenoxuron and azaridacthin against Tetranychus urticae. Exp Appl Acarol 58 (4): 395-405. DOI https:10.1007/s10493-012-9594-1

Isman MB. 2006. Botanical insecticides, deterrents, and repellents in modern agriculture and an increasingly regulated world. Annu Rev Entomol 51: 45-66. DOI: 10.1146/annurev.ento.51.110104.151146

Jamali F, Sohrabi F, Kohanmoo MA. 2021. Entomopathogenic fungi and plant essential oils are not compatible in controlling Tribolium castaneum (Herbst). J Plant Dis Prot 128: 799-808. DOI: 10.1007/s41348-021-00430-5

Jin X, Hayes CK, Harman GE. 1992. Principles in the development of biological control systems employing Trichoderma species against soil-borne plant pathogenic fungi. In: Leatham G.F. (ed.). Frontiers in Industrial Mycology. Chapman \& Hall, New York.

Leatemia JA, Isman, M. B. 2004. Insecticidal activity of crude seed extracts of Annona spp., Lansium domesticum and Sandoricum koetjape against lepidopteran larvae. Phytoparasitica, 31 (1): 30-37. DOI: $10.1007 / \mathrm{BF} 02980856$

Lofego AC, Rezende JM, Verona RLC, Feres RJF. 2013. Mites (Acari) associated with three species of the genus Jatropha (Euphorbiaceae) in Brazil, with emphasis on Jatropha curcas. Syst Appl Acarol 18 (4): 411-423. DOI: 10.11158/saa.18.4.10

Martins CC, Alves LFA., Mamprim AP, Souza LPA. 2016. Selection and characterization of Beauveria spp. isolates to control the broad mite Polyphagotarsonemus latus (Banks, 1904) (Acari: Tarsonemidae). Braz J Biol 76 (3): 629-637. DOI:10.1590/1519-6984.22614

Maryam A, Omoy TR, Mulyana T. 2004. Evaluation of botanical insecticide against Palpita unionalis on melati. Proceeding of the Florikultura National Seminar. Bogor, 4-5 August 2020. [Indonesian]

Mascarin GM, Lopes RB, Delaliber Jr. Í, Fernandes ÉVK, Luz C, Faria M. 2019. Current status and perspectives of fungal entomopathogen used for microbial control of arthropod pests in Brazil. J Invertebr Pathol 165: 46-53. DOI: 10.1016/j.jip.2018.01.001

Meftaul IM, Venkateswarlu K, Dharmarajan R, Annamalai P, Megharaj M. 2020. Pesticides in the urban environment: A potential threat that knocks at the door. Sci Total Environ 711: 134612. DOI: 10.1016/j.scitotenv.2019.134612

Mills NJ, Beers EH, Shearer PW, Unruh TR, Amarasekare KG. 2016. Comparative analysis of pesticide effects on natural enemies in western orchards: A synthesis of laboratory bioassay data. Biol Control 102: 17-25. DOI: 10.1016/j.biocontrol.2015.05.006

Moghadamtousi SZ, Fadaeinasab M, Nikzad S, Mohan G, Ali HM, Kadir HA. 2015. Annona muricata (Annonaceae): A review of its traditional uses, isolated acetogenins and biological activities. Int J Mol Sci 16 (7): 15625-15658. DOI: 10.3390/ijms 160715625

Mohan MC, Reddy NP, Devi UK, Kongara R, Sharma HC. 2007. Growth and insect assay of Beauveria bassiana with neem to test their compatibility and synergism. Biocontrol Sci Technol 17(10): 10591069. DOI: $10.1080 / 09583150701714551$

Nugroho I, Ibrahim YB. 2004. Bioassay of some entomopathogenic fungi against broad mite (Polyphagotarsonemus latus Banks). Int J Agric Biol 6: 223-225

Ntaribi T, Paul DI. 2018. Status of Jatropha plants farming for biodiesel production in Rwanda. Energy Sustain Dev 47: 133-142. DOI: 10.1016/j.esd.2018.09.009

Oliveira DGP, Pauli G, Mascarin GM, Delalibera I. 2015. A protocol for determination of conidial viability of the fungal entomopathogens Beauveria bassiana and Metarhizium anisopliae from commercial products. J Microbiol Methods 119: 44-52. DOI: 10.1016/j.mimet.2015.09.021

Puspitarini RD, Fernando I, Rachmawati R, Hadi MS, Rizali A. 2021. Host plant variability affects the development and reproduction of Tetranychus urticae. Int J Acarol. DOI: $10.1080 / 01647954.2021 .1915377$

Quesada-Moraga E, Navas-Cortes JA, Maranhao EAA, Ortiz-Urquiza A, Santiago-Alvarez C. 2007. Factors affecting the occurrence and distribution of entomopathogenic fungi in natural and cultivated soils. Mycol Res 111: 947-966. DOI:10.1016/j.mycres.2007.06.006

Ravaomanarivo LHR, Razafindraleva HA, Raharimala FN, Rasoahantaveloniaina B, Ravelonandro PH, Mavingui P. 2014. Efficacy of seed extracts of Annona squamosa and Annona muricata (Annonaceae) for the control of Aedes albopictus and Culex quinquefasciatus (Culicidae). Asian Pac J Trop Biomed 4(10): 798806. DOI:10.12980/APJTB.4.2014C1264

Ribeiro LP, Blume E, Bogorni PC, Dequech STB, Brand SC, Junges E. 2012. Compatibility of Beauveria bassiana commercial isolate with botanical insecticides utilized in organic crops in southern Brazil. Biol Agric Hortic 28(4): 223-240. DOI:10.1080/01448765.2012.735088

Ribeiro LP, Akhtar Y, Vendramim JD, Isman MB. 2014. Comparative bioactivity of selected seed extracts from Brazilian Annona species and an acetogenin-based commercial bioinsecticide against Trichoplusia ni and Myzus persicae. Crop Prot 62: 100-106. DOI: 10.1016/j.cropro.2014.04.013

Rosado JF, Picanço MC, Sarmento RA, da Silva RS, Pedro-Neto M, Carvalho MA, Erasmo EA, Silva LC. 2015. Seasonal variation in the populations of Polyphagotarsonemus latus and Tetranychus bastosi in physic nut (Jatropha curcas) plantations. Exp Appl Acarol 66 (3): 415-426. DOI: 10.1007/s10493-015-9911-6

Rosado JF, Sarmento RA, Pedro-Neto M, Galdino TV, Marques RV, Erasmo EA, Picanço MC. 2014. Sampling plans for pest mites on physic nut. Exp Appl Acarol 63(4): 521-534. DOI: 10.1007/s10493014-9804-0

Rossi-Zalaf LS, Alves SB. 2006. Susceptibility of Brevipalpus phoenicis to entomopathogenic fungi. Exp Appl Acarol 40 (1): 37-47. DOI: 10.1007/s10493-006-9024-3

Sahayaraj K, Namasivayam, SKJ, Rathi JM. 2011. Compatibility of entomopathogenic fungi with extracts of plants and commercial botanicals. Afr J Biotechnol 10 (7): 933-938

Sánchez-Peña SR, Lara SJ, Medina RF. 2011. Occurrence of entomopathogenic fungi from agricultural and natural ecosystems in Saltillo, Mexico, and their virulence towards thrips and whiteflies. J Insect Sci 11: 1-10. DOI: 10.1673/031.011.010110.1673/031.011.0101

Sarmento RA, Rodrigues DM, Faraji F, Erasmo EA, Lemos F, Teodoro AV, Kikuchi WT, do Santos GR, Pallini A. 2011. Suitability of the predatory mites Iphiseiodes zuluagai and Euseius concordis in controlling Polyphagotarsonemus latus and Tetranychus bastosi on Jatropha curcas plants in Brazil. Exp Appl Acarol 53 (3): 203-214. DOI: $10.1007 / \mathrm{s} 10493-010-9396-2$

Scott IM, Jensen HR, Philogène BJR, Arnason JT. 2008. A review of Piper spp. (Piperaceae) phytochemistry, insecticidal activity and mode of action. Phytochem Rev 7: 65-75. DOI:10.1007/s11101-0069058-5

Sharma L, Oliveira I, Torres L, Marques G. 2018. Entomopathogenic fungi in Portuguese vineyards soils: suggesting a 'Galleria-Tenebriobait method' as bait-insects Galleria and Tenebrio significantly underestimate the respective recoveries of Metarhizium (roberstii) and Beauveria (bassiana). MycoKeys 38: 1-23. DOI: 10.3897/mycokeys.38.26790 
Shi WB, Feng MG 2004. Lethal effect of Beauveria bassiana, Metarhizium anisopliae, and Paecilomyces fumosoroseus on the eggs of Tetranychus cinnabarinus (Acari: Tetranychidae) with a description of a mite egg bioassay system. Biol Control 30 (2): 165173. DOI: $10.1016 /$ j.biocontrol.2004.01.017

Sidibe S, Blin J, Daho T, Vaitilingom G, Koulidiati J. 2020. Comparative study of three ways of using Jatropha curcas vegetable oil in a direct injection diesel engine. Scientific African 7: e00290. DOI: 10.1016/j.sciaf.2020.e00290

Silitonga AS, Atabani AE, Mahlia TMI, Masjuki HH, Badruddin IA, Mekhilef S. 2011. A review on prospect of Jatropha curcas for biodiesel in Indonesia. Renew Sustain Energy Rev 15 (8): 3733-3756. DOI: $10.1016 /$ j.rser.2011.07.011

Streinbürk J, Tavakkol S, Francis G, Bockhorn H. 2019. Jatropha Potential of biomass steam processing to convert crop residues to biocoal and thus triple the marketable energy output per unit plantation area. Ind Crop Prod 136: 59-65. DOI: 10.1016/j.indcrop.2019.04.065

van Leeuwen T, Tirry L, Yamamoto A, Nauen R, Dermauw W. 2015. The economic importance of acaricides in the control of phytophagous mites and an update on recent acaricide mode of action research. Pestic Biochem Phys 121: 12-21. DOI: 10.1016/j.pestbp.2014.12.009

Vänninen I, Tyni-Juslin J, Hokkanen H. Persistence of augmented Metarhizium anisopliae and Beauveria bassiana in Finnish agricultural soil. Biocontrol 45: 201-222. DOI: 10.1023/A:1009998919531
Venzon M, Rosado MC, Molina-Rugama AJ, Duarte VS, Dias R, Pallini A. 2008. Acaricidal efficacy of neem against Polyphagotarsonemus latus (Banks) (Acari: Tarsonemidae). Crop Prot 27: 869-872. DOI: 10.1016/j.cropro.2007.10.001

Weintraub PG, Kleitman S, Mori R, Shapira N, Palevsky E. 2003. Control of the broad mite (Polyphagotarsonemus latus (Banks)) on organic greenhouse sweet peppers (Capsicum annиum $\mathrm{L}$.) with the predatory mite, Neoseiulus cucumeris (Oudemans). Biol Control 27 (3): 300309. DOI: $10.1016 / \mathrm{S} 1049-9644(03) 00069-0$

Wu S, Xie H, Li M, Xu X, Lei Z. 2016. Highly virulent Beauveria bassiana strains against the two-spotted spider mite, Tetranychus urticae, show no pathogenicity against five phytoseiid mite species. Exp Appl Acarol 70 (4): 421-435. DOI: 10.1007/s10493-016-0090-x

Xavier-Santos S, Lopes RB, Faria M. 2011. Emulsifiable oils protect Metarhizium robertsii and Metarhizium pingshaense conidia from imbibitional damage. Biol Control 59 (2): 261-267. DOI: 10.1016/j.biocontrol.2011.08.003

Xiao G, Ying SH, Zheng P, Wang ZL, Zhang S, ZXie XQ, Shang Y, St. Leger RJ, Zhao GP, Wang C, Feng MG. 2012. Genomic perspectives on the evolution of fungal entomopathogenicity in Beauveria bassiana. Sci Rep 2: 1-10. DOI:10.1038/srep00483 